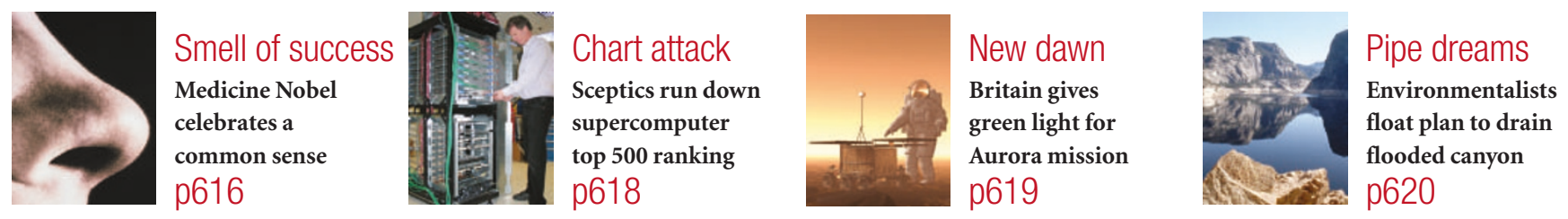

\title{
US universities up in arms over licence plans for foreign staff
}

Geoff Brumfiel, Washington

Scientists and students from countries such as China and India may soon be required to obtain special licences before they can operate laboratory equipment in the US universities where they work.

The change would require scientists from a list of "countries of concern" - including Russia, Pakistan, India and China to seek a licence from the US Department of Commerce before operating, installing, maintaining or repairing equipment on the department's extensive list of controlled technologies. It is being proposed by the department as a "clarification" of an existing regulation.

But the idea is raising alarm among top university officials. They fear that the modification will at best create a mountain of additional paperwork, and at worst restrict international scientists' ability to participate in research. A group of 22 university presidents, led by Charles Vest of the Massachusetts Institute of Technology in Cambridge, wrote to government officials on 9 September to express their concern. Their letter to Condoleezza Rice - President George Bush's national security adviser - and other top officials warned that the proposed changes "would compromise the international competitiveness and leadership of our institutions".

At the heart of the debate is a long-standing set of regulations covering the export of sensitive technologies to foreign countries. Known broadly as the Export Administration Regulations, the rules are designed to prevent the transfer of equipment that could be used to further a nation's military capabilities. The regulations also prohibit citizens from these countries from obtaining detailed knowledge of controlled technologies while visiting the United States. Foreign nationals from countries of concern must obtain a licence from
Commerce Control List - Index

\section{Description}

Avipment, parts, and components

Bacteria

Bacteria

Commerce Control List - Index

Description

Airborne communication equipment

Airborne

Ba Aircraft, civil

Ba Aircraft, dem

Aircraft, trair

ircraft brea

ircraft ine

lexandrit

Alexandrit

ign \& e

lignmen

lkylphes

fllash

loy str

Alloyed

\section{Commerce}

Blanks, Zinc selenide $(\mathrm{ZnSe})$ substrate

Blanks, Zinc sulphide (ZnS) substrate

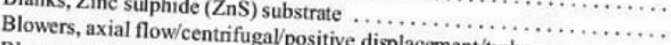

Blowers, positive displage displacement/turbo

Bluetongue virus

Body armor .

Boilers, Marine .

Bombs, smoke

Bonding equipment

Boring equipment, large

Boring machines ( $\mathrm{CNC}$ )

Boring machines (CNC)

Boron

C) .....

a US list of technologies

licences for their use by foreigners in academic labs.

which pieces of lab equipment are considered as "controlled" will prove a formidable task. The list includes thousands of entries, ranging from those with an obvious security application, such as "body armor", to more general items such as "bacteria".

"I think it is fair to say that most universities don't even know what they have," Hardy says. Even if the controlled equipment can be inventoried, he says, filing individual licences for each foreign student and researcher working on the apparatus would place enormous strain on university resources.

Peter Lichtenbaum, assistant secretary for export administration at the commerce department, says he is aware of the problems that the revised regulations could pose, and he is working with universities to address the issue.

Lichtenbaum stresses that the

the commerce department's Bureau of Industry and Security before working on technologically sensitive equipment.

Historically, universities and government laboratories doing basic research have been exempt from these rules. But in a report issued in March, the commerce department's independent inspector-general warned that although research results may be exempt, the equipment used to conduct research is not, and that researchers should be required to apply for licences before using it.

"We think that the implications are extremely serious," says Robert Hardy, director of contracts and intellectual property management at the Council on Government Relations, a Washington-based association for research universities. "It's one thing to place restrictions on who can come into the country to work and study. But what is being proposed now are further controls on what they're allowed to do on campus."

Hardy predicts that merely determining legal understanding of what constitutes the "operation" of a piece of equipment is different from the usual definition. Pressing a few buttons on a machine to make a measurement is unlikely to fall under the regulations, he says. But a licence would be required if technologically significant information was gained from using the equipment. He also says the department is considering an exemption that would allow foreign researchers access to the minimum technology needed to operate equipment safely and effectively.

But he says that universities and foreign scientists must be prepared to accept some changes in the way they do research. "We know that foreign governments are targeting universities," he says. "It's not something we can turn a blind eye to. This will require some work and there's no way around that."

The commerce department is expected to issue a draft regulation later this autumn, with a final version to be published next year. 